\title{
Wybrane konteksty wizerunku nauczyciela wczesnej edukacji Na podstawie badań nauczycieli i rodziców sześciolatków w Polsce
}

Wybrane konteksty wizerunku nauczycieli wczesnej edukacji. Na podstawie badań nauczycieli i rodziców sześciolatków w Polsce

Wychowywanie dzieci w opiniach nauczycieli wczesnej edukacji na tle opinii rodziców dzieci. Na podstawie badań nauczycieli i rodziców sześciolatków w Polsce.

\section{Problem}

W nawiązaniu do kilku moich wypowiedzi w latach 2007-2010 za autorytetami utrzymuję tezę, że system edukacyjny danego kraju odzwierciedla normy socjokulturowe szerszego środowiska (politycznego, ekonomicznego), czyli czy to jak organizujemy szkoły i czego uczymy naszych uczniów jest zależne od tego jak społeczeństwo postrzega edukację i jej rolę? ${ }^{1}$

Jak wiadomo, wizerunek szkoły przyszłości opisywany jest między innymi za pomocą sześciu scenariuszy, OECD (Organization for Econimic Cooperation and Development $)^{2}$. Scenariusze (1. szkoła jako zbiurokratyzowany system, 2. szkoła w modelu rynkowym, 3. szkoła jako instytucja publiczna, centrum społeczne, 4. szkoła jako organizacja kształcąca, 5. rozpad szkoły,

\footnotetext{
${ }^{1}$ M. Donnellan, School, Home and Society: How does the Sociocultural Environment transform Educational Systems? Tłumaczenie: A. Murzyn: Szkoła, dom i społeczeństwo: w jaki sposób środowisko socjokulturowe przeksztatca systemy edukacyjne?, [w:] Przemiany edukacyjne w Polsce i na świecie a modele wychowania, pod red. W. Korzeniowska, Kraków 2001.

${ }^{2}$ M. Sysło, Sześć scenariuszy dotyczacych przyszłości szkoły. Informatyka w Szkole, XIX, Szczecin, 10-13.09. 2003 (opracowanie, które powstało na podstawie artykułu The OECD Schooling Scenarios in Bief, www.oecd.org oraz artykułu A. Michel, Six scenarios sur l’Ecole, Futuribles, 266/2001, z języka francuskiego przełożyła E. Poterałowicz).
} 
nieformalne kształcenie w sieci, 6. dezintegracja szkoły, ucieczka nauczycieli) są koncepcjami zmian w szkole, jakie muszą nastąpić $\mathrm{z}$ uwagi na zmiany otoczenia społecznego, jak wzrastająca rola uczniów w szkole, ich rodziców, jako „konsumentów” w edukacji, kryzys w dopływie do szkół dobrze przygotowanych nauczycieli, wpływ technologii informacyjnej, taki, że tradycyjny system klasowo-lekcyjny z nauczycielem w centrum musi ulec zmianie. Uznaje się, że przyszła relacja szkoły $\mathrm{z}$ otoczeniem ma olbrzymi wpływ na dalsze funkcjonowanie członków społeczeństwa, większy niż jakakolwiek treść nauczania. Dla wyrobienia umiejętności życiowych, stwierdził Zygmunt Bauman, sposób przekazywania umiejętności i wiedzy (deutero-learning) jest ważniejszy niż treści nauczania (proto-learning) ${ }^{3}$. Obecnie, przykładowo w Irlandii, wydajność na polu edukacji określa nastawienie na wykształconą siłę robocza, nacisk kładzie się na umiejętności biznesowe, obsługę komputera, dużo więcej uwagi poświęca się potrzebom specjalnym uczniów. Chodzi o wykształconych, umiejących pisać i czytać, zdyscyplinowanych młodych ludzi. Na Seszelach struktura systemu edukacyjnego stanowiła miniaturę domu (system dyktatury rządu). Chodziło o kształcenie ludzi zdyscyplinowanych, pracowitych, obdarzających nauczycieli szacunkiem. Z kolei w Anglii wiele szkół przyjęło rolę domu, przejmując wobec zjawiska rodzin nuklearnych funkcje domu i edukując w zakresie postaw moralnych, religijnych, obywatelskich. Ma miejsce edukacja osobowa, społeczna i zdrowotna, $\mathrm{P} \mathrm{S} \mathrm{H} \mathrm{E}$.

Wizerunek nauczyciela w szkole jest pochodną przyjętej koncepcji szkoły, od miejsca centralnego, autorytarnego, w szkole do osoby tylko wspomagającej rozwój ucznia. Jak stwierdziła Wanda Dróżka, w historii edukacji nauczyciele zajmowali różne pozycje wobec zmian ${ }^{5}$. W systemach państwowych, konserwatywnych, tradycyjnych sam nauczyciel był przedmiotem oddziaływań zewnętrznych. Chodziło o adaptację młodych do zastanych struktur społeczno-politycznych. Nauczyciel pozostawał wobec ustanawianej poza nim wiedzy i wobec systemu państwowego. W takich warunkach nie musiał być odpowiedzialny za rezultaty swojej pracy. W systemach humanistycznych demokracji liberalnej, po 1968 roku, nauczyciel był postrzegany jako twórca zmiany (podmiot).

Jego zadaniem byto wspieranie poprzez edukacje transgresji osobowej uczqcych się, w warunkach pluralizmu kultury, autonomii osobowej, indywidualności i niezależności systemowej. Nauczyciela tworzyła osobowość, autentyczny system wartości oraz wiedza $i$ doświadczenie praktyczne, ograniczone przeważnie do przestrzeni klasy szkolnej oraz problemów lokalnych. W warun-

${ }^{3}$ Z. Bauman, Ponowoczesna szkoła życia, [w:] Alternatywy myślenia o edukacji, wybór tekstów, pod red. Z. Kwieciński, Warszawa 2000.

${ }^{4}$ M. Donnellan, School, Home and Society ...

${ }^{5}$ W. Dróżka, Generacja wielkiej zmiany. Studium autobiografii średniego pokolenia nauczycieli polskich 2004, Kielce 2008. 
kach autonomii szkót wzrastała zdecydowanie odpowiedzialność osobista nauczyciela. Od nauczyciela wymagano refleksji praktycznej na podbudowie teorii tzw. ugruntowanej, rozwijanej na obszarze fenomenologicznych i narracyjnych badań jakościowych, co znacznie zawężato jego świadomość makrostrukturalnych uwarunkowań edukacji oraz życia społecznego w szerszej skali ${ }^{6}$.

W obecnej, globalnej cywilizacji późnej nowoczesności nauczyciel zyskuje pozycję interpretatora i mediatora zmiany, stwierdziła Wanda Dróżka. W procesie edukacyjnym odpowiedzialność jest podzielana pomiędzy podmioty edukacyjne i społeczne. Wszyscy ponoszą odpowiedzialność. Globalne zależności współczesnego życia sprawiają, że nie wystarcza już opierać się tylko na praktycznej, lokalnej, osobistej wiedzy. W odniesieniu do wizji nauczyciela, chodzi tu o nauczyciela w roli transformatywnego intelektualisty, ,posługującego się refleksją dyskursywną", świadomego powiązań i złożoności relacji między wiedzą, władzą, ekonomią, polityką. Zatem obecnie mamy już ewidentnie z przemianą pozycji nauczyciela od nauczyciela „zależnego”, ,podporządkowanego systemowi” do nauczyciela „niezależnego" od systemu, do nauczyciela „współzależnego”. Dzisiejszy nauczyciel musi umieć funkcjonować między sferą indywidualną a społeczną

Częściowo analizę taką z punktu widzenia nierówności społecznych, w tym niepowodzeń uczniów, przeprowadzili Krzysztof Krzychała i Beata Zamorska. Autorzy poddali oglądowi nauczycieli traktując tę grupę jako zespół ludzi, którzy poprzez wspólną pracę w określonej szkole posiadają podobne doświadczenia i wypracowują zbliżone wzory orientacji, charakterystyczne dla konkretnej szkoły ${ }^{8}$. Wzory orientacji, zdaniem autorów, składają się z dwóch zasobów wiedzy pragmatycznej, z jednej strony tej, która w badaniach identyfikowana jest jako standaryzowane i zinstytucjonalizowane reguły działania, oraz z drugiej strony ramy orientacji wyznaczone przez pierwotną socjalizację łączącą się z uwarunkowaniami środowiskowymi. Ramy orientacji łaczq się z środowiskowa mentalnościq, przynależnościq do określonego kręgu lokalnej spoteczności, wynikaja z profilu kapitału społeczno-kulturowego konkretnej grupy nauczycieli ${ }^{9}$.

$\mathrm{W}$ zbiorowo podzielanym schemacie orientacji nauczyciele przyjmują logikę systemu szkolnej edukacji. Jest to podstawy punkt odniesienia, ale dużą rolę ma tu również habitus środowiskowy samych nauczycieli. Nauczyciele sami doświadczali/doświadczają społeczne podstawy edukacji, jak środowiskowe wsparcie aspiracji edukacji, osobiste kontakty z dobrymi uczniami, studia, awans zawodowy, sami też przeszli drogą socjalizacji pierwotnej, wszystko, co

\footnotetext{
${ }^{6}$ Tamże, s. 18.

${ }^{7}$ Tamże, s. 19.

${ }^{8}$ K. Krzychała, B. Zamorska, Nauczyciele wobec edukacyjnej obcości - rekonstrukcja kolektywnych wzorów orientacji, [w:] R. Kwiecińska, M. Szymański (red.), Nauczyciel wobec zróżnicowań społecznych, Kraków 2010.

${ }^{9}$ Tamże, s. 28.
} 
ułatwia im identyfikację z logiką szkoły. Ponadto łączy ich logika pracy w konkretnym zespole nauczycieli, oraz wiedza podzielana przez konkretny zespół nauczycieli. W świecie uczniów jest trochę inaczej, bowiem są uczniowie dobrze wkomponowani w logikę szkoły, ale są i tacy, którzy mają z tym trudności. Zaś z punktu widzenia reakcji nauczycieli na uczniów, którym obca jest logika szkoły można wyróżnić różne wzory orientacji nauczycieli wobec edukacyjnej obcości (najczęściej wobec uczniów pozostawionych samych sobie ze szkoła, z rodzin o niskim kapitale kulturowym, ze środowisk marginalizowanych). U podstaw ich wyróżniania jest: 1 . nasilenie orientacji co do poznawczego odrzucenia edukacyjnej obcości (nauczyciele metodyczni, lub nauczyciele umęczeni, którzy nie kładą nacisku na wagę własnej refleksji nad uwarunkowaniami niepowodzeń uczniów), 2. orientacja na akceptujące poznanie obcości edukacyjnej (nauczyciele mediujący i swojacy, którzy serio włączają we własny wzór orientacji perspektywę uczniów), 3. orientacja na aktywne reagowanie na edukacyjną obcość (nauczyciele metodyczni i mediujący, ważne cele edukacyjne realizujący wspólnie), 4. orientacja na brak poczucia sprawstwa wobec edukacyjnej obcości (nauczyciele umęczeni i swojacy, u których dominuje poczucia o niewielkiej skuteczności swoich działań, brak sensu wielu wysiłków $)^{10}$. Wobec propozycji autorów otwarty pozostaje problem nakładania się wzorów orientacji, czy dominujących typów. Dla niniejszych rozważań ważne jest ustalenie, że dzisiejszy nauczyciel funkcjonuje między sferą indywidualną i społeczną a sposób jego funkcjonowania wyznacza przyjmowany system orientacji, w tym światopoglądowy, uwarunkowany doświadczeniami społeczno-kulturowymi. Możemy powtórzyć, że dzisiejszy nauczyciel ma być nauczycielem „niezależnym” od systemu. Ma to jednak być nauczyciel „współzależny” z szeroko rozpoznawanymi podmiotami w systemie.

Kontekst wizerunku współczesnego nauczyciela określa inne już pojmowanie nowoczesności, niż dawnej. Analizę taką przeprowadził Mirosław J. Szymański. Dawniej, stwierdza autor, nowoczesność chętnie przeciwstawiano tradycjonalizmowi. $O$ ile tradycjonalizm utożsamiano $z$ wstecznictwem, niewie$d z a$, zacofaniem i zabobonami, o tyle nowoczesność kojarzona była z postępem, racjonalizmem, coraz lepszym panowaniem człowieka nad siłami przyrody i losami spoteczeństwa ${ }^{11}$. Za autorytetami można przyjąć, że konstytutywnymi aspektami nowoczesności są indywidualizm, dyferencjacja, racjonalizm, ekonomizm, ekspansywność. W nowoczesności centralne miejsce w społeczeństwie zajmuja jednostki i znacznie ograniczona została zasada dziedziczenia pozycji społecznych przez młodsze pokolenie. W wyznaczaniu losów życiowych

${ }^{10}$ Tamże. s. 33-34.

${ }^{11}$ M. Szymański, Indywidualizacja i zróżnicowania społeczne w okresie późnej nowoczesności, [w:] R. Kwiecińska, M. Szymański (red.), Nauczyciel wobec zróżnicowań społecznych, Kraków 2010. 
jednostek zmniejszeniu uległa rola klas i warstw społecznych, płci, czy miejsca zamieszkania. Mirosław Szymański stwierdza, że wraz z większym zaawansowaniem nowoczesności większego znaczenia nabiera pula pozycji osiaganych dzięki zdolnościom, wykształceniu, przedsiębiorczości, nakładowi pracy. Nie zmienia to faktu, że nowoczesność generuje "nowe" zróżnicowania możliwości jednostek (w literaturze opisywane są jako zjawiska alienacji, anomii, rozpadu wspólnot cementujących społeczeństwa tradycyjne, marginalizacji i wykluczeń, grabieżczej eksploatacji zasobów surowcowych, czy „luki ludzkiej”, jako dystansu między złożonością świata a naszymi możliwościami jej sprostania). W późnej zaś nowoczesności pewnym jest tylko to, że świat jest nieprzewidywalny.

Indywidualizm jednostki w czasie późnej nowoczesności nie jest sprawą oczywistą, stwierdza Szymański ${ }^{12}$. Nowoczesność radykalną, inaczej ponowoczesność, jak się ją określa, cechuje wiele wspólnego z charakterem indywidualizacji w dzisiejszych czasach. W obszarze gospodarki chodzi o jej rynkowy charakter, w obszarze usług upodabnianie się ich do przemysłu, w obszarze kultury zaś o zacieranie się granic między kulturą wyższą a popularną. Nowoczesne społeczeństwa stworzyły mit osiagalności wszystkich dóbr dla każdego. Mowa tu o micie, bowiem jedne nierówności zastępowane są innymi stwierdza Szymański (jak klasowe, rasowe przez kataklizmy, migracje, rozwody), dawne patologie nowymi (jak alkoholizm przez narkomanię), tradycyjna przemoc jej nowymi formami (przykładowo bicie dzieci przez ośmieszanie w sms-ch) ${ }^{13}$. Oznacza to, że nowoczesna jednostka musi pokonać wiele barier, które leżą przede wszystkim w sferze psychiki. Rzadko przy tym może liczyć na innych. Wyznacznikiem indywidualizacji jednostki w ponowoczesnych czasach stały się w znacznej mierze samotność i ryzyko, poczucie niepewności, lęk.

W dookreślaniu zakresu i kierunku oddziaływań szkoły ważne jest pojęcie socjalizacji. Pojęcie to zabezpiecza, uznaje Marzena Nowicka, przed uproszczonym oglądem sytuacji szkolnych w kategoriach świadomie podejmowanych wpływów wychowawczych ${ }^{14}$. Socjalizacja dotyczy procesu uspołeczniania jednostki (dzieci, uczniów, młodzieży, innych). Najbardziej rozpowszechnionym jest podział tego procesu na fazy. Mówi się wtedy o socjalizacji pierwotnej (obejmującej dzieciństwo, zatem dokonującej się głównie w rodzinie) oraz o socjalizacji wtórnej (ta dotyczy starszych dzieci, młodzieży, całego dorosłego życia człowieka, bo współcześnie zakłada się, że chodzi tu o proces permanentny). Szczegółowe rozumienie socjalizacji wyznacza jednak przyjmowana teoria.

12 Tamże, s. 14.

${ }^{13}$ Tamże, s. 17.

${ }^{14}$ M. Nowicka, Oblicza szkolnej socjalizacji, [w:] D. Klus-Stańska, M. Szczepska-Pustkowska (red.), Pedagogika wczesnoszkolna - dyskursy, problemy, rozwiazania, Warszawa, 2009. 
Z perspektywy socjologicznej zwraca się uwagę na związki socjalizacji szkolnej z szerzej ujmowanym funkcjonowaniem społeczeństwa.

Przykładowo w teorii strukturalno-funkcjonalnej celem socjalizacji jest przygotowanie jednostki do pełnienia ról społecznych. Zwolennicy funkcjonalizти akcentuja odejście od indywidualizmu i podporzqdkowanie zachowania jednostki ogólnym wymogom, przedstawiajac wizje bezkonfliktowego społeczeństwa podległego kontroli ${ }^{15}$. Oświata $\mathrm{w}$ tym podejściu to znakomite narzędzie kontroli społeczeństwa nad prawidłowym rozwojem jego samego. Funkcjonalizm cechuje wiara w merytokratyczność systemu szkolnego, traktowanie szkoły jako instytucji działającej na korzyść jednostki, z tym, że taka socjalizacja ma charakter adaptacyjny, jednostka zaś jest bierna, konformistyczna w pełnionych rolach, nie przekraczająca predyspozycji biologicznych i predyspozycji, jakie wyznacza jej społeczeństwo.

W teoriach konfliktowych społeczeństwo jest postrzegane jako twór pełen sprzeczności i napięć, które generują różnego typu nierówności (ekonomiczne, kulturowe, polityczne). Konflikty są widoczne w relacjach interpersonalnych między osobami różnych płci, zawodów, zajmowanych stanowisk. Każda grupa zaspokaja swoje potrzeby, zaś przyłączające się do niej jednostki znajdują się natychmiast pod wpływem interesów członków grupy ${ }^{16}$. Szkoła to miniatura całego społeczeństwa w teoriach konfliktowych. Relacji nauczyciel-uczeń towarzyszy dominacja. Szkoła odgrywa istotną rolę w reprodukowaniu nierówności społecznych, poprzez przygotowywanie uczniów do uczestnictwa w zastanym świecie pracy (efektywnych robotników). Socjalizacja szkolna sprzyja reprodukowaniu wyalienowanej osobowości społecznej, której potrzeby rozwojowe nie są spełniane. W samej szkole liczą się te same cechy, jakie potrzebne są dobrze wykwalifikowanym robotnikom. Są nimi wytrwałość, zależność, porządek. Sukcesy szkolne, jak wykazały klasyczne badania przeprowadzane w nurcie konfliktowym, zdecydowanie nie łączą się z kreatywnością, niezależnością. Nie sposób omówić tutaj wszystkich teorii z grupy konfliktowych, na pewno jednak socjalizacja traktowana jest $\mathrm{w}$ nich jako determinująca zachowanie człowieka.

W socjologicznych podejściach interpretatywnych (interakcjonizm symboliczny, fenomenologia, inne) przyjmuje się, że działając w interakcjach świadomie ukierunkowujemy i modyfikujemy nasze zachowanie $w$ zależności od reakcji partnera interakcji i naszych własnych intencji ${ }^{17}$. Interakcje są ośrodkiem wytwarzania znaczeń. Szkoła wyznacza różne warunki tworzenia znaczeń w umyśle dziecka. W naszej rzeczywistości szkolnej najczęściej arbitralnie

\footnotetext{
15 Tamże, s. 267.

${ }^{16}$ Tamże, s. 270.

${ }^{17}$ Tamże, s. 279.
} 
narzuca się znaczenia sformalizowane, nienegocjonowalne $i$ odarte $z$ realnego kontekstu społecznego (Dorota Klus-Stańska nazywa ten proces treningiem indoktrynacyjnym $)^{18}$. Wychowankowie w tych teoriach nie są bierni. Mają oni za zadanie podejmować trud określania swoich społecznych ról i zobowiązań. Wynika z tego, że członkowie tej samej socjalizowanej społeczności są różni, różnią się postawami, przekonaniami, zachowaniami w tych samych sytuacjach. Socjalizację szkolną wyróżnia akcentowanie osobotwórczego wymiaru interakcji. Uczeń sam musi osiagnąć równowagę między osobistymi dążeniami, pragnieniami a wymaganiami społecznymi.

W podejściach psychologicznych ujęcia socjalizacyjne określa przyjęta koncepcja natury człowieka. O procesie traktuje przedmiotowa literatura. $\mathrm{Z}$ punktu widzenia pożądanych cech jednostki (dziecka/ucznia/człowieka dorosłego) można dodać tylko, że podejście behawioralne akcentuje posłuszeństwo jako podstawę relacji interpersonalnych. W ujęciach humanistycznych akceptowana jest podmiotowość wychowanka, jego autokreacyjne możliwości, kształtowana jest pozytywna samoocena. W ujęciach poznawczych zaś, dialog stanowi podstawę komunikacji, ważne jest nabywanie przez dzieci szerokich kompetencji poznawczych, interakcyjnych, moralnych, kształtowana jest samodzielność dzieci w formułowaniu sądów i wyjaśnień.

Krótkie odwołanie do procesów socjalizacyjnych ma tutaj miejsce z uwagi na to, że nauczyciel musi być krytyczny wobec własnej preorientacji teoretycznej i socjalizacyjnych korzeni. Zabezpiecza to przed nieświadomym uczestnictwem w procesach, które mogą tylko z pozoru wydawać się dobre i zapewniać jednostce satysfakcjonujące życie. Dotyczy to zarówno samego nauczyciela, jak i będącego z nim w interakcji ucznia.

$\mathrm{Na}$ tle refleksji nad wizerunkiem szkoły, wizerunkiem nauczyciela, oraz specyfiką przemian społecznych w późnej nowoczesności w artykule eksponowane jest postrzeganie przez nauczycieli wczesnej edukacji kierunku kształtowania pożądanych cech dzieci dla nowoczesności. To jakie opinie w tym zakresie mają nauczyciele przedstawione jest w świetle opinii rodziców dzieci.

Jakimi cechami należy obdarzyć dzieci aby przygotować je do życia w dzisiejszych czasach? Jakie środowiska mają największy wpływ na wychowywanie dzieci? Czy rodzice mogą nauczyć dzieci „sztuki życia”? Czy płeć decyduje o sposobach wychowywania dzieci? Na ile opinie nauczycieli na te tematy sa inne niż opinie rodziców? Jaki jest empiryczny wizerunek opinii nauczyciela wczesnej edukacji na tle opinii rodziców? W konsekwencji na ile szkoła, reprezentowana przez nauczycieli, może potencjalnie zgodnie nadawać ten sam kierunek wychowania dzieci, jaki za ważny uznają rodzice? Jakie są podstawy dla potencjalnego partnerstwa edukacyjnego w Polsce?

18 Tamże, s. 280. 


\section{Materiał i metoda}

Dane zebrano w roku 2006 w ramach projektu badawczego Dziecko sześcioletnie u progu nauki szkolnej (finansowanego przez Europejski Fundusz Społeczny i Ministerstwo Edukacji Narodowej) ${ }^{19}$. Celem badań była diagnoza gotowości szkolnej dzieci 6-letnich. Badania zrealizowano w kwietniu-maju 2006 (etap I: badaniom poddano 34225 dzieci kończących roczne przygotowanie do nauki szkolnej w Polsce, w większości urodzone w roku 1999), oraz we wrześniu-październiku 2006 (etap II: zbadano 33616 dzieci rozpoczynających roczne przygotowanie do nauki szkolnej, w większości urodzone w roku 2000). Dobór placówek i dzieci do badań miał charakter doboru losowego, warstwowozespołowego. Próby badawcze były reprezentatywne ze względu na typ placówki (przedszkole, szkoła), środowisko (miasto, wieś), płeć dzieci. Badania przeprowadzono w 1316 placówkach publicznych, JST (Jednostki Samorządu Terytorialnego), ogólnodostępnych. Próby dobierałam osobiście ${ }^{20}$. Niezależnie od tego zbadano 1723 sześciolatków w 48 placówkach (placówki w większości same zgłaszały chęć udziału w badaniach). Jest to celowa próba zrealizowana w drugiej sekwencji badań. Charakteryzuje ją wysoka nadreprezentacja dzieci miejskich i dzieci poddanych edukacji przedszkolnej w przedszkolach.

Badano również rodziców wyznaczonych do badań dzieci, oraz ich nauczycieli (nauczycieli wczesnej edukacji, w przedszkolach i szkołach). W pierwszej sekwencji zbadano 31389 rodziców dzieci sześcioletnich; w drugiej zaś 29987. Dobór nauczycieli do badań miał charakter doboru celowego. Zbadano 6136 nauczycieli, w tym, na etapie pierwszym 3189 (52,0\%), drugim 2947 (48,0\%); w miastach $55,2 \%$, w środowiskach wiejskich $44,8 \%$; w przedszkolach $54,4 \%$, za w szkołach $45,6 \%{ }^{21}$.

Prezentowane w tym artykule dane dotyczą tej części badań nad rodzicami i nauczycielami, która dotyczy opinii na temat środowiskowych podstaw wychowywania dzieci. Dane uzyskano za pomocą kwestionariuszy własnej konstrukcji, wysoce standaryzowanych, u podstaw których legły między innymi koncepcje nisz ekologicznych rozwoju dzieci ${ }^{22}$. Za literaturą przyjęto, że okazje dla doświadczeń edukacyjnych dzieci stwarzają dorośli. Dorośli rozumiani są przy tym szeroko. Chodzi zarówno o dorosłych w środowiskach rodzinnych (mama, tata, opiekunowie, babcia, dziadek, inni), jak i środowiska lokalnego dziecka, w tym szkolnego (nauczyciel, inni). Dla wychowywania dzieci ważna

${ }^{19}$ Autorka pełniła funkcję Ogólnopolskiego Koordynatora Badań ds. Rodziny i Nauczyciela.

${ }^{20}$ B. Walasek, Schemat doboru próby, [w:] A. Kopik (red.), Sześciolatki w Polsce. Raport 2006. Diagnoza badanych sfer rozwoju, Bydgoszcz 2007; W tym samym tomie: B. Walasek Charakterystyka próby wedlug klasyfikacji.

${ }^{21}$ Tamże.

${ }^{22}$ M. Karwowska-Struczyk, Nisze ekologiczne a rozwój dziecka, Warszawa 2000. 
jest informacja, na ile wyróżnione środowiska wychowawcze są zgodne co do przyjmowanych założeń wychowywania dzieci? Odpowiedź na takie pytanie stanowi też jeden $\mathrm{z}$ potencjalnych wskaźników partnerstwa edukacyjnego w szkole (spójności zachowań różnych jej podmiotów, w tym rodziców, wobec dzieci).

Powyższy problem pośrednio rozstrzygano $\mathrm{w}$ badaniach stosując ten sam pomiar $^{23}$. Rodzicom i nauczycielom w jednym z bloków pytań kwestionariuszy zadano kilka identycznych pytań z zakresu problematyki wychowywania. Wybiórczo tylko zostaną objęte analizą i przedstawione w wynikach badań. Wyniki badań dotyczą kompletów odpowiedzi dla zmiennych objętych analizą (7 zmiennych), stąd dane dotyczą opinii 27192 rodziców dzieci 6-letnich badanych wiosną 2006 roku, 25745 rodziców badanych tego samego roku w czasie jesieni, oraz 2770 nauczycieli (wiosna) i 2495 (jesień). W każdej badanej podzbiorowości jest to około $85-87 \%$ próby badawczej.

Badani rodzice sześciolatków to osoby młode (trzydziestolatki), posiadające wykształcenie średnie lub wyższe. Na tle zbiorowości Polaków z czasu badań można uznać, że są lepiej wykształceni. Przeważa jednak jeszcze wykształcenie zawodowe (tabela 1).

Tabela 1. Rozkłady wykształcenia badanych osób (\%)

\begin{tabular}{|c|c|c|c|c|}
\hline \multirow{2}{*}{ Kategorie wykształcenia rodziców } & \multicolumn{2}{|c|}{ ETAP I $(N=27192)$} & \multicolumn{2}{|c|}{ ETAP II $(N=25745)$} \\
\hline & Matka & Ojciec & Matka & Ojciec \\
\hline Podstawowe i niżej & 7,8 & 7,7 & 7,3 & 7,4 \\
\hline Zasadnicze zawodowe & 28,8 & 43,1 & 28,0 & 41,9 \\
\hline Niepełne średnie & 3,3 & 3,1 & 3,2 & 2,9 \\
\hline Średnie ogólnokształcące & 7,0 & 3,8 & 7,1 & 3,9 \\
\hline Średnie zawodowe & 19,4 & 18,2 & 19,0 & 18,0 \\
\hline Policealne/pomaturalne & 8,9 & 3,4 & 8,7 & 3,4 \\
\hline Nieukończone wyższe & 2,6 & 2,4 & 2,7 & 2,4 \\
\hline Licencjat/inżynierskie & 3,1 & 2,8 & 3,8 & 3,3 \\
\hline Ukończone magisterskie & 13,2 & 8,2 & 14,3 & 9,0 \\
\hline Braki danych & 5,9 & 7,4 & 6,0 & 7,8 \\
\hline Kategorie wykształcenia nauczycieli & \multicolumn{2}{|c|}{ ETAP I $(\mathrm{N}=2770))$} & \multicolumn{2}{|c|}{ ETAP II $(\mathrm{N}=2495))$} \\
\hline 1 & & \multicolumn{2}{|c|}{3} \\
\hline Średnie & \multicolumn{2}{|c|}{5,9} & \multicolumn{2}{|c|}{4,7} \\
\hline Studium nauczycielskie/pedagogiczne & \multicolumn{2}{|c|}{25,6} & \multicolumn{2}{|c|}{24,4} \\
\hline Wyższa Szkoła/Akademia pedagogiczna & \multicolumn{2}{|c|}{39,8} & \multicolumn{2}{|c|}{41,5} \\
\hline
\end{tabular}

${ }^{23}$ B. Walasek, Schemat doboru... 
Tabela 1 (cd.)

\begin{tabular}{|l|c|c|}
\hline \multicolumn{1}{|c|}{1} & 2 & 2 \\
\hline Ukończone licencjackie/inżynierskie & 15,6 & 15,5 \\
\hline Ukończone magisterskie/lekarskie & 46,3 & 45,1 \\
\hline Egzaminy kwalifikacyjne ODN & 4,7 & 5,6 \\
\hline Podyplomowe nauczycielskie & 4,0 & 4,6 \\
\hline Doktorat & 0,3 & 0,2 \\
\hline Studia podyplomowe/kursy & 37,3 & 34,4 \\
\hline Inne & 7,9 & 4,7 \\
\hline
\end{tabular}

Legenda: w grupach nauczycieli dane w tej tabeli nie sumują się do $100 \% \mathrm{z}$ uwagi na wielokrotne odpowiedzi (prawdopodobnie w tym świetle należy też odczytywać procent wskazań na wykształcenie średnie)

\section{Wyniki badań}

Badania własne dowodzą bardzo wysokich aspiracji edukacyjnych rodziców dzieci co do kształcenia własnych dzieci, ich realności i to niezależnie od płci dziecka $^{24}$. Rodzina to środowisko przede wszystkim odpowiedzialne za kształtowanie u dzieci cech osobowości, jak duma z siebie, wytrwałość, szkoła zaś ma odpowiadać za kształcenie umiejętności szkolnych, motoryki, chyba tez twórczego wyrażania przeżyć. Zwraca uwagę podobieństwo ocen rodziców i nauczycieli, oraz ewidentny podział odpowiedzialności między środowisko rodzinne i szkolne, co do kształcenia rodzajów umiejętności dzieci. Co ciekawe, pozytywnie wyselekcjonowani, jeśli uznać, że chodzi tu o zbiorowość określona próbą celową, również nie różnią się zasadniczo w opiniach od pozostałych badanych osób. Dane przedstawiono w odnośnych środowiskach naukowych ${ }^{25}$, zaś w kontynuacji rozważań warto chyba zwrócić uwagę na zmienną psychologiczną będącą między innymi wskaźnikiem poczucia sprawstwa rodziców wobec wychowywania własnych dzieci.

${ }^{24} \mathrm{~B}$. Walasek-Jarosz, „Ja” realne, ,,ja” aspirujace...(aspiracje edukacyjne rodziców sześciolatków wobec dojrzatości szkolnej ich dzieci), [w:] I. Pufal-Struzik (red.), Oblicza „JA”. „Ja” twórcze, aspirujace, zwielokrotnione, wyczerpane, noetyczne, zagrożone patologia, Kraków 2009.

${ }^{25}$ Tamże; B. Walasek, Nauczyciel. Środowiska rozwoju umiejętności dzieci. [w:] A. Kopik (red.), Sześciolatki w Polsce. Raport 2006. Diagnoza badanych sfer rozwoju, Bydgoszcz 2007; W tym samym tomie: B. Walasek, Rodzic. Środowiska rozwoju umiejętności dzieci; B. WalasekJarosz, Aspiracje edukacyjne rodziców sześciolatków wobec kryteriów dojrzatości szkolnej dzieci, [w:] E. Jaszczyszyn, J. Szada-Borzyszkowska (red.), Edukacja dziecka, mity i fakty, Białystok 2010. 
Czy zdaniem Pani(a) rodzice mogą nauczyć dziecko „sztuki życia”? W odpowiedziach badanych rodziców i nauczycieli stwierdzono interesujący rezultat (rycina 1 i 2).
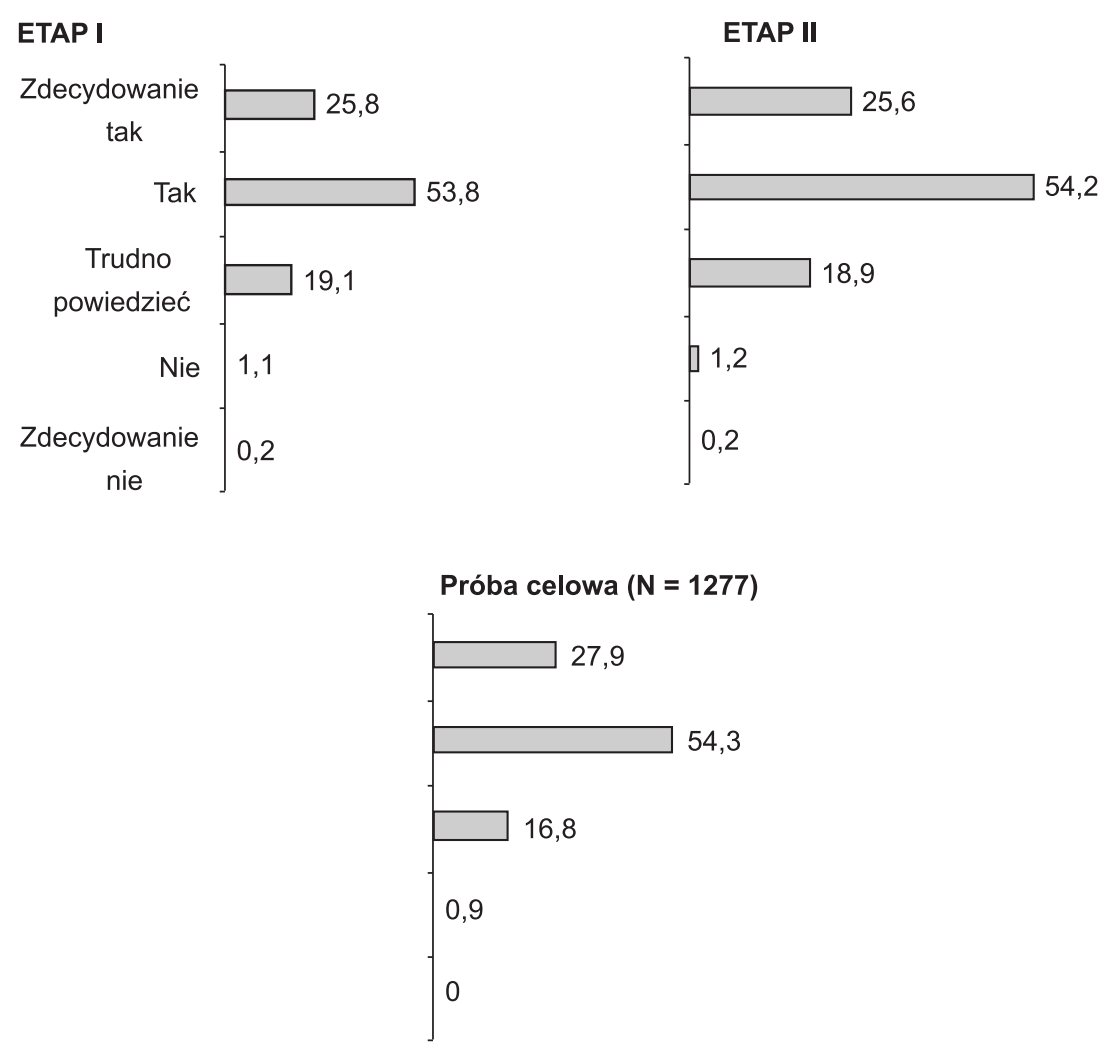

Rycina 1. Wybory rodziców dotyczące uznania, że rodzice mogą nauczyć dziecko „sztuki życia” (\%)

Zwraca uwagę niewielki udział tych rodziców, którzy uznali, że „nie” (296 osób), lub że ,zdecydowanie nie” jest to możliwe (49 osób), etap I. Stanowią oni mniej niż 1,5\% zbiorowości (w etapie drugim: 306 i 39 osób; w próbie celowe zaś: 12 osób i dodatkowo nikt nie wskazał odpowiedzi „zdecydowanie nie”). Procent osób wstrzymujących się od odpowiedzi również jest niewielki. Wyselekcjonowanie badanych ze względu na status ekonomiczny, czy wykształcenie, co ma miejsce w próbie celowej, podobnie jak wśród nauczycieli, nie zmienia, lecz wzmacnia wynik (rycina 1). Podobnie wśród nauczycieli tylko 37 z nich nie uznaje by było to możliwe i jedynie 9 osób stwierdza, że „zdecydowanie nie" jest to możliwe. W sekwencji drugiej badań było to już odpowiednio 44 i 5 osób (rycina 2). 


\section{ETAP I}

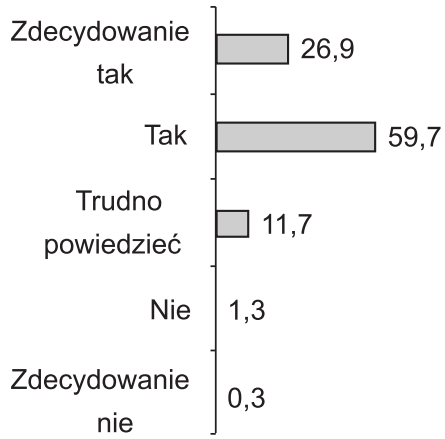

ETAP ||

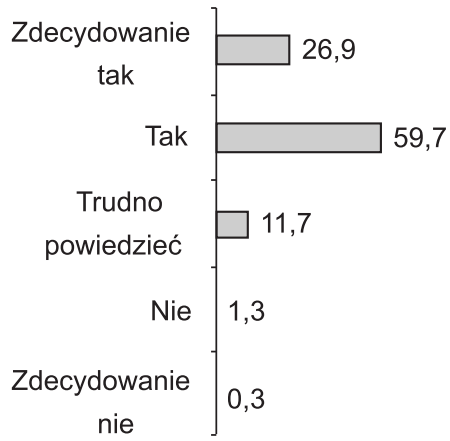

Rycina 2. Wybory nauczycieli dotyczące uznania, że rodzice mogą nauczyć dziecko „sztuki życia” (\%)

$\mathrm{Z}$ listy cech, jakie należy w dzisiejszych czasach rozwijać u dziecka w procesie wychowania i nauczania badani na pierwszym miejscu wskazują umiejętność samodzielnego myślenia, zaś na drugim posiadanie inicjatywy, umiejętność obrony swoich racji.
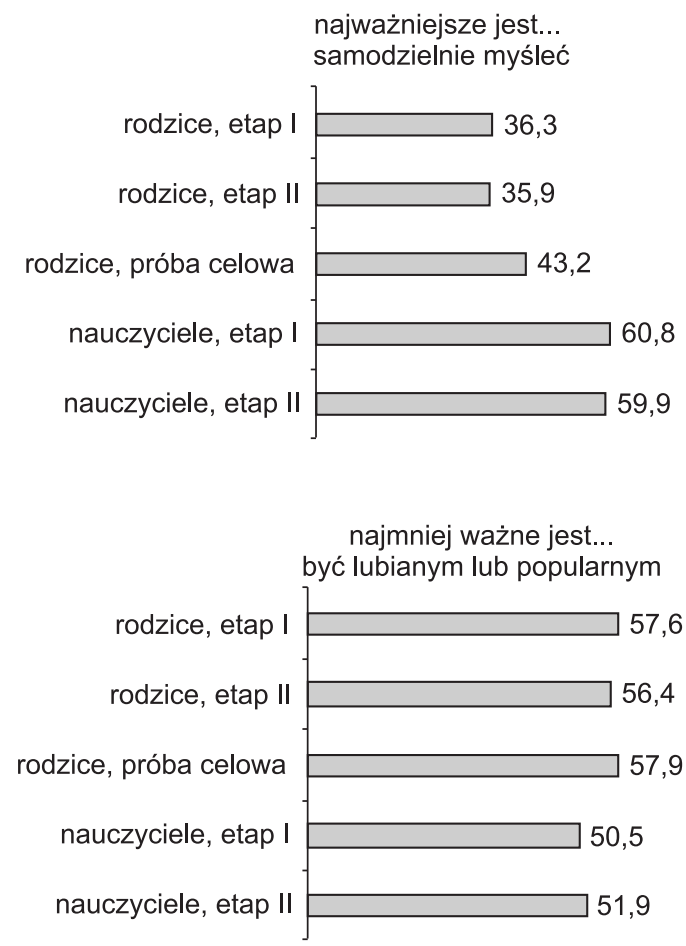

Rycina 3. Wybory cech, jakie powinny posiadać dzieci w dzisiejszych czasach (\%) 
Dokonany przez badanych wybór jest naturalnie pochodną sytuacji badawczej, w jakiej zostali postawieni (kafeterii wskazań). Zwraca jednak uwage podobieństwo wskazań nauczycieli i rodziców, zaś listę cech, z jakiej wybierano przedstawia tabela 2 i 3 (badani poproszeni byli o wskazanie cechy najważniejszej i najmniej ważnej).

Tabela 2. Najbardziej pożądane cechy dzieci w dzisiejszych czasach (\%)

\begin{tabular}{|l|c|c|c|c|c|c|}
\hline \multirow{2}{*}{$\begin{array}{c}\text { Lista wybieranych cech } \\
\text { wg kolejności } \\
\text { kwestionariusza badań }\end{array}$} & $\begin{array}{c}\text { rodzice, } \\
\text { etap I }\end{array}$ & $\begin{array}{c}\text { rodzice, } \\
\text { etap II }\end{array}$ & $\begin{array}{c}\text { rodzice, } \\
\text { próba celowa }\end{array}$ & $\begin{array}{c}\text { nauczyciele, } \\
\text { etap I }\end{array}$ & $\begin{array}{c}\text { nauczyciele, } \\
\text { etap II }\end{array}$ \\
\cline { 2 - 6 } & \multicolumn{5}{|c|}{ Najważniejsze jest.... } \\
\hline być posłusznym & 2,7 & 2,6 & 2,0 & 0,3 & 0,6 \\
\hline $\begin{array}{l}\text { być lubianym lub popu- } \\
\text { larnym }\end{array}$ & 0,7 & 0,6 & 0,5 & 0,2 & 0,5 \\
\hline samodzielnie myśleć & $\mathbf{3 6 , 3}$ & $\mathbf{3 5 , 9}$ & $\mathbf{4 3 , 2}$ & $\mathbf{6 0 , 8}$ & $\mathbf{5 9 , 9}$ \\
\hline być pracowitym & 13,8 & 14,1 & 10,9 & 4,6 & 6,6 \\
\hline $\begin{array}{l}\text { pomagać innym, gdy po- } \\
\text { trzebują pomocy }\end{array}$ & 11,1 & 11,1 & 9,5 & 4,2 & 5,3 \\
\hline $\begin{array}{l}\text { mieć inicjatywę, bronić } \\
\text { swoich racji }\end{array}$ & $\mathbf{2 0 , 6}$ & $\mathbf{1 9 , 3}$ & $\mathbf{1 9 , 0}$ & $\mathbf{2 9 , 9}$ & $\mathbf{2 7 , 1}$ \\
\hline $\begin{array}{l}\text { wiele w/w cech } \\
\text { (minimum dwie) }\end{array}$ & 14,7 & 16,4 & 14,9 & $\mathrm{X}$ & $\mathrm{X}$ \\
\hline
\end{tabular}

Tabela 3. Najmniej pożądane cechy dzieci w dzisiejszych czasach (\%)

\begin{tabular}{|l|c|c|c|c|c|c|}
\hline \multirow{2}{*}{$\begin{array}{c}\text { Lista wybieranych cech } \\
\text { wg kolejności } \\
\text { kwestionariusza badań }\end{array}$} & $\begin{array}{c}\text { rodzice, } \\
\text { etap I }\end{array}$ & $\begin{array}{c}\text { rodzice, } \\
\text { etap II }\end{array}$ & $\begin{array}{c}\text { rodzice, } \\
\text { próba celowa }\end{array}$ & $\begin{array}{c}\text { nauczyciele, } \\
\text { etap I }\end{array}$ & $\begin{array}{c}\text { nauczyciele, } \\
\text { etap II }\end{array}$ \\
\cline { 2 - 6 } & \multicolumn{5}{|c|}{ Najmniej ważne jest.... } \\
\hline być posłusznym & 24,5 & 24,7 & 27,3 & 43,7 & 41,4 \\
\hline $\begin{array}{l}\text { być lubianym lub popu- } \\
\text { larnym }\end{array}$ & 57,6 & 56,4 & 57,9 & 50,5 & 51,9 \\
\hline samodzielnie myśleć & 1,8 & 1,7 & 1,4 & 0,7 & 1,0 \\
\hline być pracowitym & 1,8 & 1,7 & 1,1 & 1,4 & 1,4 \\
\hline $\begin{array}{l}\text { pomagać innym, gdy po- } \\
\text { trzebują pomocy }\end{array}$ & 2,0 & 1,8 & 1,5 & 0,8 & 1,4 \\
\hline $\begin{array}{l}\text { mieć inicjatywę, bronić } \\
\text { swoich racji }\end{array}$ & 8,2 & 8,6 & 6,5 & 2,9 & 2,7 \\
\hline $\begin{array}{l}\text { wiele w/w cech } \\
\text { (minimum dwie) }\end{array}$ & 4,2 & 5,0 & 4,2 & $\mathrm{X}$ & $\mathrm{X}$ \\
\hline
\end{tabular}


Na pytanie o ważność różnych środowisk w procesie wychowywania dzieci większość badanych stwierdziło, że największy wpływ na wychowywanie dzieci ma rodzina (rodzice, etap I: 70,9\%; rodzice, etap II: 70,3\%, rodzice, próba celowa: 73,0\%, nauczyciele, etap I: $92,1 \%$, nauczyciele, etap II: $88,4 \%$ ). Znacznie mniejszą wage przywiązywano do szkoły, jako środowiska wychowawczego (odpowiednio, jak wyżej: $7,1 \%, 6,5 \%, 4,8 \%$, na drugim miejscu u nauczycieli: $47,8 \%, 44,2 \%)$, czy grupy rówieśniczej $(3,9 \%, 3,9 \%, 3,8 \%$, na drugim miejscu: $32,9 \%, 36,6 \%$ ). Wynik nie zaskakuje, choć może mieć to związek z odpowiedziami udzielanymi ściśle w obrębie badanej grupy dzieci sześcioletnich. Media i otoczenie lokalne nie są w opinii badanych najważniejszymi środowiskami wychowywania dzieci. Odpowiedzi nauczycieli, inne niż rodziców, należy interpretować tym, że nauczyciele zostali poroszeni o nadanie rang wszystkim ,środowiskom”, rodzice zaś o wskazanie środowiska najważniejszego, najmniej ważnego.

Tabela 4. Źródła wiedzy rodziców o sposobach wychowywania własnych dzieci (\%)

\begin{tabular}{|l|c|c|c|c|c|}
\hline \multicolumn{1}{|c|}{ Kategorie wskazań } & $\begin{array}{c}\text { rodzice, etap } \\
\text { I }\end{array}$ & $\begin{array}{c}\text { rodzice, etap } \\
\text { II }\end{array}$ & $\begin{array}{c}\text { rodzice, } \\
\text { próba celowa }\end{array}$ & $\begin{array}{c}\text { nauczyciele, } \\
\text { etap I }\end{array}$ & $\begin{array}{c}\text { nauczyciele, } \\
\text { etap II }\end{array}$ \\
\hline $\begin{array}{l}\text { na podstawie rodzinnej } \\
\text { tradycji }\end{array}$ & 33,0 & 33,0 & 30,8 & 45,8 & 47,2 \\
\hline $\begin{array}{l}\text { własne doświadczenia } \\
\text { z dzieciństwa }\end{array}$ & 62,9 & 63,0 & 59,8 & 62,5 & 60,6 \\
\hline $\begin{array}{l}\text { naśladownictwo innych w } \\
\text { środowisku lokalnym }\end{array}$ & 3,5 & 3,7 & 3,1 & 15,7 & 14,9 \\
\hline $\begin{array}{l}\text { obserwacja własnego } \\
\text { dziecka }\end{array}$ & 70,9 & 70,1 & 74,6 & 49,3 & 46,3 \\
\hline od własnych rodziców & 52,2 & 52,7 & 53,6 & 66,3 & 64,4 \\
\hline $\begin{array}{l}\text { nabytej wiedzy (czytanie, } \\
\text { szkoła, kursy) }\end{array}$ & 51,2 & 49,0 & 53,9 & 41,5 & 41,8 \\
\hline Z mediów & 5,1 & 6,4 & 6,6 & 18,3 & 20,2 \\
\hline inne źródla & 5,9 & 5,8 & 7,4 & 1,7 & 2,2 \\
\hline
\end{tabular}

Tabela 5. Uznanie płci jako czynnika różnicującego wychowywanie dzieci (\%)

\begin{tabular}{|l|c|c|c|c|}
\hline \multicolumn{1}{|c|}{$\begin{array}{c}\text { Badana } \\
\text { zbiorowość }\end{array}$} & \multicolumn{4}{|c|}{ Udzielona odpowiedź... } \\
\hline & zdecydowanie tak & tak & nie & zdecydowanie nie \\
\hline rodzice, etap I & 6,3 & 30,0 & 47,5 & 16,2 \\
\hline rodzice, etap II & 5,6 & 27,6 & 49,6 & 17,1 \\
\hline rodzice, próba celowa & 7,5 & 29,0 & 47,6 & 15,9 \\
\hline nauczyciele, etap I & 5,4 & 33,9 & 45,3 & 15,3 \\
\hline nauczyciele, etap II & 6,5 & 30,8 & 46,2 & 16,4 \\
\hline
\end{tabular}


Tabela 6. Uznanie płci jako czynnika różnicującego wychowywanie dzieci a ,uczenie dzieci sztuki życia"(\%)

\begin{tabular}{|c|c|c|c|c|}
\hline \multirow{2}{*}{$\begin{array}{l}\text { Uznanie, że dziecko można nauczyć } \\
\text { „sztuki życia” }\end{array}$} & \multicolumn{4}{|c|}{ Czynnik płci jako różnicujący wychowywanie dzieci } \\
\hline & $\begin{array}{l}\text { zdecydowanie } \\
\text { tak }\end{array}$ & tak & nie & $\begin{array}{c}\text { zdecydowanie } \\
\text { nie }\end{array}$ \\
\hline \multicolumn{5}{|l|}{ rodzice, etap I } \\
\hline zdecydowanie tak & 38,9 & 23,0 & 22,9 & 34,4 \\
\hline Tak & 41,5 & 57,5 & 55,9 & 45,7 \\
\hline \multicolumn{5}{|l|}{ rodzice etap II } \\
\hline zdecydowanie tak & 39,4 & 22,9 & 22,4 & 34,5 \\
\hline Tak & 41,9 & 58,1 & 56,9 & 44,3 \\
\hline \multicolumn{5}{|l|}{ rodzice, próba celowa } \\
\hline zdecydowanie tak & 49,0 & 25,9 & 23,0 & 36,0 \\
\hline Tak & 27,1 & 57,3 & 58,2 & 50,2 \\
\hline \multicolumn{5}{|l|}{ nauczyciele, etap I } \\
\hline zdecydowanie tak & 32,0 & 23,6 & 25,4 & 36,9 \\
\hline Tak & 41,9 & 58,1 & 56,9 & 44,3 \\
\hline \multicolumn{5}{|l|}{ nauczyciele, etap II } \\
\hline zdecydowanie tak & 40,5 & 28,9 & 29,6 & 40,5 \\
\hline Tak & 41,7 & 58,8 & 58,0 & 46,6 \\
\hline
\end{tabular}

\section{W konkluzji...}

Zaprezentowane wcześniej cztery wzory orientacji nie wydają się proste i podatne na zmianę i przesunięcia, stwierdzają autorzy koncepcji ${ }^{26}$. Wyodrębnione wzory dotyczyły nauczycieli gimnazjów i klas IV-VI szkoły podstawowej. Autorzy stwierdzają, że ważne byłoby przyjrzenie się wzorom orientacji nauczycieli wychowania przedszkolnego i poczatkowego. Wiele wskazuje, że na tym poziomie nauczania środowiskowe i biograficzne ramy orientacji nauczycielek (niemal wyłacznie) odgrywaja jeszcze bardziej znaczqca role. Za Lucyną Kopciewicz uznają dalej, iż $w$ zawodowy habitus nauczycielek edukacji wczesnoszkolnej wpisane sq specyficzne dyspozycje (dyspozycje naturalne) kobiet, które zyskuja profesjonalny odpowiednik, sprowadzajac prace pedagogiczna do matczynej opieki sprawowanej nad dziećmi. Uwzględnienie tego aspektu w podobnym habitualnym odcieniu przez inne kolezanki z pracy, na pole edukacji instytucjonalnej, wprowadziłoby $w$ prezentowany model specyficzne przesunięcia i uszczegótowienia ${ }^{27}$.

Prowadzone w ramach badań własnych, jako wtórne, badania nauczycieli wczesnej edukacji częściowo potwierdzają wiele ustaleń, obserwacji i przewi-

\footnotetext{
${ }^{26}$ Krzychała K., Zamorska B., Nauczyciele wobec edukacyjnej..., s. 59.

${ }^{27}$ Tamże, s. 64 (kulturą uczniów i ,ludzi szkoły”, kulturą lokalnych instytucji i grup).
} 
dywań z innych badań. W tym sensie dopełniają dyskurs o nauczycielach na tym szczeblu kształcenia. Nauczyciele edukacji wczesnoszkolnej to rzeczywiście kobiety (etap I: 98,9\%; etap II: 99,5\%), w systemie polskim znakomicie wykształcone, ze stażem pracy średnio 10 do 26 lat.

W świetle ustaleń stwierdza się, że nauczyciele całkowicie uznają prawo rodziców do wychowywania własnych dzieci. Stwierdzają też, podobnie jak rodzice, że rodzice mogą nauczyć dzieci „sztuki życia”. Będzie to miało miejsce na podstawie doświadczeń własnych i obserwacji dziecka, ale i za sprawą czytania z różnych publikacji, ze szkoły, kursów. Dzieci przede wszystkim należy obdarzyć umiejętnością samodzielnego myślenia, podejmowania inicjatyw, obrony swoich racji. Mniej ważne jest posłuszeństwo, czy bycie lubianym lub popularnym.

Z jakimi zatem podmiotami edukacji mamy tutaj do czynienia? Rola nauczyciela w szkole w opinii badanych, zarówno nauczycieli, jak i rodziców, na tym etapie kształcenia dotyczy nauczyciela w społeczeństwie rynkowym, oraz społeczeństwie wiedzy. Ceniony jest indywidualizm jednostki. Nie chodzi o nauczycielskie zachowanie status guo, czy o tradycyjne społeczeństwo. Nie chodzi też jednak o działania wspólnotowe. W ponowoczesnym świecie kontrolę nad dzieckiem nie ma sprawować już tylko szkoła, ale przede wszystkim rodzina, która ulega olbrzymim przeobrażeniom (dowodzi tego choćby wykształcenie rodziców). Specyfiką polską jest zbieżność poglądów pedagogów i społeczeństwa odnośnie wymagań wobec edukacji. System cechuje pomieszanie systemu państwowego $\mathrm{z}$ prywatnym ${ }^{28}$. Badana własne takie obserwacje potwierdzają. Choć nie było to badane wprost, socjalizacja dziecka/ucznia, jaka może się tu wydarzyć, ma cechy ujęć humanistycznych i poznawczych.

Podsumowując należy zauważyć jeszcze dwa wyniki. W analizie koncepcji partnerstwa edukacyjnego Maria Mendel stwierdza, że szkoła może być miejscem należącym do wspólnoty postrzeganej w perspektywie międzykulturowości, $w$ której - tak jak szkolne mury i granice - rozpuszczq się podziaty na tych, którzy te przestrzeń opanowali i narzucaja kształt temu społecznemu konstruktowi oraz na zdominowanych, którym nie pozostaje nic innego, jak przyjać go $\langle$ bez stowa>, w milczeniu, tkwiac $w$ wymuszanej warunkami kulturze ciszy i dalej Kultura rodziców, dzisiaj ukryta i raczkujaca, mogłaby $w$ takich warun$k a c h, w$ toku interaktywnej wymiany $z$ innymi rozwijać się $i$ sprostać $w$ ten sposób wyzwaniu, jakim jest uspotecznienie szkoły poprzez aktywny udział tej czesśsi społeczności $w$ jej życiu ${ }^{29}$. Na szczeblu wczesnej edukacji, jak dowodzą przedstawione badania, istnieją podstawy do legitymizacji kultury rodzicielskiej we wspólnocie szkolnej (spójność poglądów nauczycieli rodziców sześciolatków i to w olbrzymiej próbie reprezentatywnej).

${ }^{28}$ M. Donnellan, School, Home and Society...

${ }^{29}$ M. Mendel, Nauczyciel z uczniem, rodzicami i lokalnq spotecznościq. Koncepcje partnerstwa edukacyjnego, [w:] D. Klus-Stańska, M. Szczepska-Pustkowska (red.), Pedagogika wczesnoszkolna - dyskursy, problemy, rozwiazania, Warszawa 2009. 
Drugi wynik dotyczy poglądów, czy płeć kulturowa różnicuje sposoby wychowywania dzieci? Choć problem jest szerszy ${ }^{30}$, należy wskazać, że nie mamy tu do czynienia $\mathrm{z}$ indywidualizacja jednostki niezależnie od płci. Poza tym utrwalony zawodowy autorytet nauczycielek wczesnej edukacji (nauczycielkimatki) gubi je, wręcz degraduje zwłaszcza w wymiarze intelektualnym. Sprawa jest o tyle istotna, że wprawdzie jest mniejszy udział tych nauczycieli (też rodziców), którzy zdecydowanie uznają płeć jako czynnik różnicujący wychowywanie dzieci, to jednak ma to związek z większym poczuciem sprawstwa, co do możliwości nauczenia dzieci sztuki życia, jak w ostatniej tabeli. W obliczu dużych badanych podzbiorowości, badanych w różnym czasie, mocno różnych ze względu na cechy społeczno-demograficzne taki wynik nie wydaje się przypadkowy. Oznacza to, iż w społeczeństwie ponad 5 do 8 procent rodziców i nauczycieli deterministycznie uznaje ,wćwiczanie” w kulturowe role jako składnik wychowania.

\section{$* * *$}

Jakimi cechami należy obdarzyć dzieci aby przygotować je do życia w dzisiejszych czasach? Odpowiedź: ważne jest samodzielne myślenie, posiadanie inicjatywy, obrona swoich racji.

Jakie środowiska mają największy wpływ na wychowywanie dzieci? Odpowiedź: jest to rodzina.

Czy rodzice mogą nauczyć dzieci „sztuki życia”? Odpowiedź: ogólne tak.

Czy płeć decyduje o sposobach wychowywania dzieci? Odpowiedź: obecnie już nie.

$\mathrm{Na}$ ile opinie nauczycieli na te tematy są inne niż opinie rodziców? Odpowiedź: ogólnie są bardzo podobne.

Jaki jest empiryczny wizerunek nauczyciela wczesnej edukacji na te wizerunku rodziców? Odpowiedź: kontekst życiowy nauczyciela wyznacza jego światopogląd na temat wychowywania dzieci i to w symbiozie ze światopoglądem przyjmowanym w środowisku lokalnym.

W konsekwencji na ile szkoła, reprezentowana przez nauczycieli, może potencjalnie zgodnie nadawać ten sam kierunek wychowania dzieci, jaki za ważny uznają go rodzice? Odpowiedź: badania dowodzą bardzo dobrych podstaw światopoglądowych dla aktywizacji rodziców jako podmiotu szkoły.

Odpowiedzi na postawione pytania prezentowane są wprost na rycinach i wykresach. Kontekst życiowy nauczyciela stanowi ważny składnik jego wizerunku. W odpowiedzi należy też mieć nadzieje, że rodzice i dalej szkoła

${ }^{30}$ L. Kopciewicz, Wczesna edukacja i płeć kulturowa, [w:] D. Klus-Stańska, M. Szczepska-Pustkowska (red.), Pedagogika wczesnoszkolna - dyskursy, problemy, rozwiązania, Warszawa 2009. 
a $\mathrm{w}$ konsekwencji same dzieci $\mathrm{w}$ przyszłości poradzą sobie $\mathrm{z}$ negatywnymi wyznacznikami indywidualizacji jednostki za jakie w ponowoczesnych czasach należy uznać samotność i ryzyko, poczucie niepewności, lęk.

BARBARA WALASEK-JAROSZ

\section{Chosen contexts of the image of an early education teacher On the basis of the research of teachers and six-year-olds`s parents in Poland}

The article presents the empirical material proving the similarity of early education teachers' views to the views of children's parents on shaping the desired features of children in future. The resaerch was carried out as part of the research project „A six-year-old child on the threshold of school learning" (financed by Europejski Fundusz Społeczny i Ministerstwo Edukacji Narodowej - European Social Fund and Ministry of National Education Ministry). The research was conducted twice, in the year 2006, on the selected sample of six-year-olds in Poland and their parents (altogether about 70 thousand, which makes $8-10 \%$ of the population depending on the province). The samples were chosen by the author. The article showes the data concerning the cohesion in spite of differences in the education levels, views of children's parents and their teachers in the scope of: 1 . the assessment of the possibility of teaching children so called ,art of life" by their parents 2 . features which, nowadays, should be given to children, 3 . the sources of knowledge of parents about the methods of bringing up children, 4. recognised by the subjects the environments of bringing up own children, 5. the subjects' opinions about the sex as a factor differentiating bringing up children. In conclusion, one should pay the attention to the life context (,empirical image of a teacher") as an important factor of fulfilling ,the desired image of a teacher" of early education at which numerous eductional ideas point. 